Archives of Agriculture and Environmental Science

\title{
Combined allelopathic effect of buckwheat and marsh pepper residues on weed management and crop performance of transplant aman rice
}

\author{
Farhana Afroz ${ }^{1}$, Md. Romij Uddin ${ }^{1^{*}}$, Ahmed Khairul Hasan ${ }^{1}$, Uttam Kumer Sarker ${ }^{1}$, Mohammad \\ Muhebbullah Ibne Hoque ${ }^{2}$ and Mohammad Akikul Islam ${ }^{3}$ \\ ${ }^{1}$ Department of Agronomy, Bangladesh Agricultural University, Mymensingh-2202, BANGLADESH \\ ${ }^{2}$ ACI Limited, Dhaka, BANGLADESH \\ ${ }^{3}$ Bangladesh Agricultural Development Corporation, Kishoreganj, BANGLADESH \\ ${ }^{*}$ Corresponding author's E-mail: romijagron@bau.edu.bd
}

\section{ARTICLE HISTORY}

Received: 13 August 2018

Revised received: 20 August 2018

Accepted: 25 August 2018

\section{Keywords}

Agricultural residues

Combined-allelopathic effect

Harvest index

Weed management

Yield efficiency

\section{ABSTRACT}

The experiment was conducted at the Agronomy Field Laboratory, Bangladesh Agricultural University, Mymensingh during the period from June to December 2016 to evaluate the suppression of weed growth through combined application of buckwheat and marsh pepper residues in transplant aman rice. The experiment consisted of three cultivars i.e. BRRI dhan56, Binadhan-12 and Nizershail, and five different crop residues with their combination such as no residues, $2.0 \mathrm{t} \mathrm{ha}^{-1}$ buckwheat residues, $2.0 \mathrm{t} \mathrm{ha}^{-1}$ marsh pepper residues, combined $0.5 \mathrm{t} \mathrm{ha}{ }^{-1}$ buckwheat and $1.0 \mathrm{t} \mathrm{ha}^{-1}$ marsh pepper residues, combined $1.0 \mathrm{t} \mathrm{ha}^{-1}$ buckwheat and $0.5 \mathrm{t} \mathrm{ha}^{-1}$ marsh pepper residues. The experiment was laid out in a randomized complete block design with three replications. Weed population and weed dry weight were significantly affected by cultivars and crop residues treatment. The maximum weed growth was noticed with no residues treatment and the minimum was found in combined $0.5 \mathrm{t} \mathrm{ha}^{-1}$ buckwheat and $1.0 \mathrm{t} \mathrm{ha}^{-1}$ marsh pepper residues. The grain yield as well as the yield contributing characters produced at BRRI dhan 56 was the highest among the studied varieties. The highest reduction of grain yield was obtained in no residues) treatment and the lowest was obtained when combined $0.5 \mathrm{t} \mathrm{ha}^{-1}$ buckwheat and $1.0 \mathrm{t} \mathrm{ha}^{-1}$ marsh pepper residues were applied. The highest numbers of effective tillers hill ${ }^{-1}$, number of grains panicle ${ }^{-1}, 1000$-grain weight, and grain and straw yields were observed in $\mathrm{W}_{3}$ treatment. BRRI dhan56 under $0.5 \mathrm{t} \mathrm{ha}^{-1}$ buckwheat and $1.0 \mathrm{t} \mathrm{ha}^{-1}$ marsh pepper residues treatment produced the highest grain yield. Results of this study indicates that combination of $0.5 \mathrm{t} \mathrm{ha}^{-1}$ buckwheat and $1.0 \mathrm{t} \mathrm{ha}^{-1}$ marsh pepper residues showed potentiality to suppress weed growth. Therefore, crop residues could be used as an alternative tool for sustainable weed management.

(C)2018 Agriculture and Environmental Science Academy

Citation of this article: Afroz, F., Uddin, M.R., Hasan, A.K., Sarker, U.K., Hoque, M.M.I. and Islam, M.A. (2018). Combined allelopathic effect of buckwheat and marsh pepper residues on weed management and crop performance of transplant aman rice. Archives of Agriculture and Environmental Science, 3(3): 289-296, https://dx.doi.org/10.26832/24566632.2018.0303012

\section{INTRODUCTION}

Bangladesh is an agricultural country with plenty of water and suitable climatic condition for rice production. In respect of the area and production, Bangladesh ranks fourth among the rice producing countries of the world following China, India and Indonesia (FAO, 2009). About $75.61 \%$ of cropped area of Bangladesh is used for rice production, with annual production of 33.83 million tons from 11.41 million hectares of land (BBS, 2013). Food production in Bangladesh is at far with increase in population growth. The population of Bangladesh is still growing by two million every year and may increase by another 30 million over the next 20 years which will require about 27.26 million tons of rice for the year 2020 (BBS, 2011). On the other hand, agricultural land is decreasing day by day. Average yield of rice is low compared with other rice producing countries like 
China, Korea, Japan, Indonesia etc. and this is due to traditional local varieties, high weed infestation and poor crop management. Among these reasons high weed infestation are most serious problems for low production of rice. Hence there is strong need to use modern science along with indigenous wisdom of farmers to use crop residues of rice production.

Weeds are one of the worst biological constrains to rice cultures. Weed competes with rice plants severely for space, nutrient, air, water and light. So, it is often said that "Crop production is a fight against weeds" (Mukhopadhyay and Ghosh, 1981). High competitive ability of weeds exerts a serious negative effect on crop production causing significant losses in crop yield. In Bangladesh, weed infestation reduces the grain yield by, 70$80 \%$ in aus rice (early summer), 30-40\% for transplanted aman rice (late summer) and 22-36\% for modern boro rice cultivars (winter rice) (Mamun, 1990; BRRI, 2008). Many investigators have reported great losses in the yield of rice due to weed infestation in different parts of the world (Nandal and Singh, 1994). Weeds are very serious problem in transplanted rice (Walia et al., 2006). Therefore, weed management have been a major challenge for crop producers from the start of agriculture. The weed species are suppressed differently by residual effect. The term allelopathy denotes the toxic effect of chemicals which are produced by one plant to another. Allelo-chemicals are released from crop plants through leaching, decomposition, root exudates of plants (Inderjit et al., 1999). Allelopathic substances are most commonly found in plants extracts and in plant residues in soil, in live plant exudates and as volatile gases liberated from leaves and rhizomes (Keely, 1987). To determine the most costeffective weed control method and sustainable crop production is the main theme in agricultural production system all over the world. Currently, researches are giving more emphasis using different crop residues to suppress weed growth. Information regarding crop residues for suppression of weed is very limited in Bangladesh. By using phytotoxic crop residues, our resourcepoor farmers will be benefited through reduction of weed control cost as well as maintain the good soil condition and no technical knowledge is needed to adopt this technique. Control of weeds in T. aman rice with environmentally sound weed management practices will increase crop productivity along with economically suitable practice.

Information regarding buckwheat and marsh pepper residues for weed management is limited in our country. However, in our country, so far, a little approach has been done to work for feasible weed control achievements in this area. So the study deserves to keep the significance in the current research interest in home and abroad of buckwheat and marsh pepper residues residual effects on weed suppressing ability and yield performance of transplant aman rice.

\section{MATERIALS AND METHODS}

\section{Experimental design and treatments}

The experiment was carried out at the Agronomy Field Laboratory of Bangladesh Agricultural University (BAU),
Mymensingh during the period from June 2016 to December 2017. The experimental site is located at $24^{\circ} 75^{\prime} \mathrm{N}$ latitude and $90^{\circ} 50^{\prime} \mathrm{E}$ longitude at an elevation of $18 \mathrm{~m}$ above the mean sea level. The experimental area is characterized by non-calcareous dark grey floodplain soil belonging to the Sonatola Soil Series under the Old Brahmaputra Floodplain, Agro-Ecological Zone 9 (UNDP and FAO, 1988). The soil of the experimental field was more or less neutral in reaction with $\mathrm{pH}$ value 6.8 , low in organic matter and fertility level. The land type was medium high with silty loam in texture. The experimental treatments consists of three varieties such as BRRI dhan56 $\left(V_{1}\right)$, Binadhan-12 $\left(V_{2}\right)$, Nizershail $\left(V_{3}\right)$ and five crop residues application viz. no crop residues $\left(\mathrm{W}_{0}\right), 2.0 \mathrm{t} \mathrm{ha}^{-1}$ buckwheat residues $\left(\mathrm{W}_{1}\right), 2.0 \mathrm{t} \mathrm{ha}^{-1}$ marsh pepper residues $\left(\mathrm{W}_{2}\right), 0.5 \mathrm{tha} \mathrm{H}^{-1}$ buckwheat and $1.0 \mathrm{t} \mathrm{ha} \mathrm{H}^{-1}$ marshpepper residues $\left(\mathrm{W}_{3}\right)$ and $1.0 \mathrm{t} \mathrm{ha}^{-1}$ buckwheat and $0.5 \mathrm{t}$ ha ${ }^{-1}$ marshpepper residues $\left(W_{4}\right)$. The experiment was laid out in a randomized complete block design with three replications.

\section{Cultivation practices of rice}

Buckwheat and Marsh pepper were grown at the Agronomy Field Laboratory, Bangladesh Agricultural University and were harvested at the time of ripening stage to collect crop residues. After collection, the crop residues were dried under shade. The studied crop residues were cut into pieces by using sickle. The field was ploughed with tractor followed by laddering. The experimental plots were fertilized with urea, triple super phosphate, muriate of potash, gypsum and zinc sulphate @ 90, 52, 60, 45, 4 kg ha-1, respectively. The entire amounts of triple super phosphate, muriate of potash, gypsum and zinc sulphate were applied at the time of final land preparation. Urea was applied in three equal installments at 15, 30 and 45 days after transplanting (DAT). The prepared buckwheat and marsh pepper residues were applied at 7 days before transplanting of T. aman rice. After that crop residues were mixed well with the soil to the respective plots. Thirty eight days old seedlings were transplanted in the well prepared puddled field on 30 July 2016 @ 3 seedlings hill ${ }^{-1}$ maintaining 25 $\mathrm{cm} \times 15 \mathrm{~cm}$ spacing. The crops were harvested at full maturity. Then the harvested crops of each plot was bundled separately, properly tagged and brought to threshing floor. The crops were then threshed and the fresh weights of grain and straw were recorded from an area of $1 \mathrm{~m}^{2}$ in the middle of each plot. The grains were cleaned and finally the weight was adjusted to a moisture content of $14 \%$. The straw was sun dried and the yields of grain and straw plot $^{-1}$ were recorded and converted to t ha ${ }^{-1}$.

\section{Statistical analysis of data}

The recorded data were compiled and tabulated for statistical analysis. Analysis of variance was done with the help of computer package, MSTAT-C program. The mean differences among the treatments were adjudged by Duncan's Multiple Range Test as laid out by Gomez and Gomez (1984).

\section{RESULTS AND DISCUSSION}

Infested weed species in the experimental field 
Five weed species belonging to 4 families infested the experimental field. The weeds of the experimental plots were Echinochloa crusgalli, Scirpus juncoides, Monochoria vaginalis, Cyperus difformis and Nymphea nouchali. Bari et al. (1995) in the experimental at BAU reported that the three important weeds of rice fields were Echinochloa crusgalli, Scirpus juncoides and Cyperus difformis.

Variety and crop residues interaction influence on Shama (Echinochloa crusgalli)

The interaction between variety and crop residues was found to be significant for weed population, dry weight and percent inhibition. The highest weed population (6.67) was found in $V_{3} W_{0}$ (Nizershail $\times$ no residues) followed by $V_{2} W_{0}$ and the lowest (0.47) was found in $\mathrm{V}_{1} \mathrm{~W}_{3}$ (BRRI dhan56 $\times$ Buckwheat residues at $0.5 \mathrm{t} \mathrm{ha}^{-1}$ and marsh pepper residues at $1.0 \mathrm{t} \mathrm{ha}^{-1}$ ) treatment (Table 1). The highest weed dry weight $(7.15 \mathrm{~g})$ was found in $\mathrm{V}_{3} \mathrm{~W}_{0}$ (Nizershail $\times$ no residues), and the lowest weed dry weight (0.83) was in $\mathrm{V}_{1} \mathrm{~W}_{3}$ (BRRI dhan $56 \times$ Buckwheat residues at 0.5 tha ${ }^{-1}$ and Marsh pepper residues at $1.0 \mathrm{t} \mathrm{ha}^{-1}$ ) treatment (Table 4).

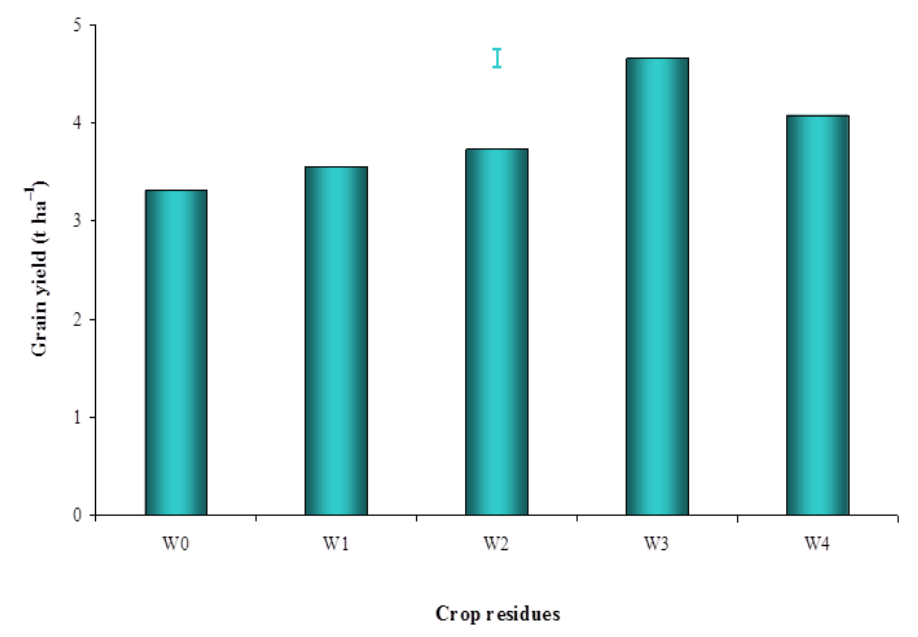

Figure 1. Grain yield as influenced by variety (Bar represents standard error mean).

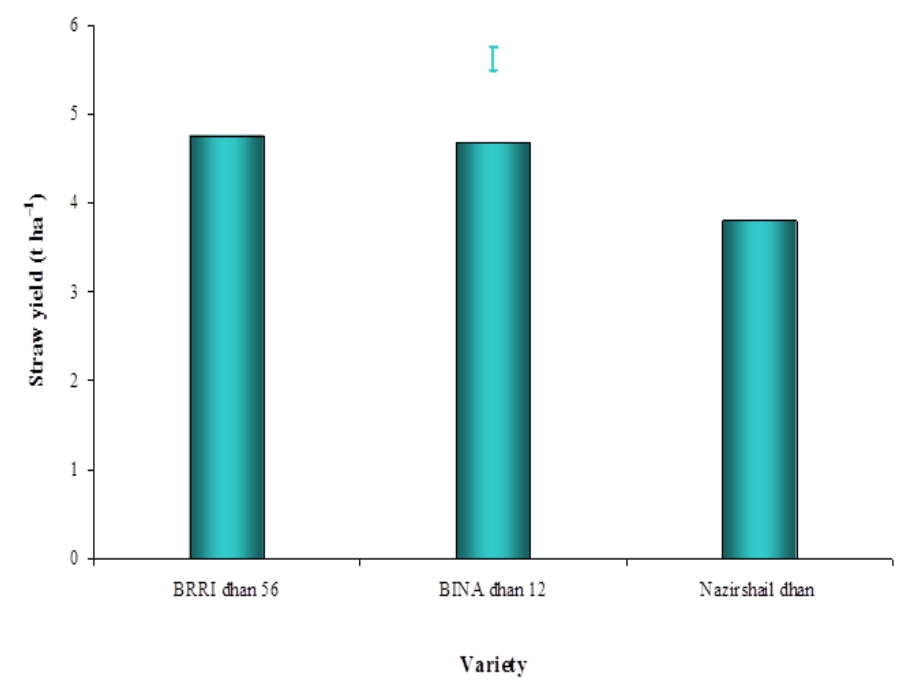

Figure 2. Grain yield as influenced by buckwheat and marsh pepper residues (Bar represents standard error mean). $W_{0}=$ No residues, $W_{1}=$ Buckwheat

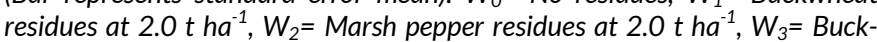
wheat residues at $0.5 \mathrm{tha}^{-1}$ and marsh pepper residues at $1.0 \mathrm{tha}^{-1}, \mathrm{~W}_{4}=$ Buckwheat residues at $1.0 \mathrm{tha}^{-1}$ and marsh pepper residues at $0.5 \mathrm{tha}^{-1}$.
Percent inhibition of weed was the highest in $\mathrm{V}_{1} \mathrm{~W}_{3}$ (BRRI dhan56 $\times$ Buckwheat residues at $0.5 \mathrm{t} \mathrm{ha}^{-1}$ and Marsh pepper residues at $1.0 \mathrm{t} \mathrm{ha}^{-1}$ ) treatment and the lowest one was observed in $\mathrm{V}_{3} \mathrm{~W}_{0}$ (Nizershail $\times$ no residues) treatment (Table 1 ).

Variety and crop residues interaction influence on Panikachu (Monochoria vaginalis)

The interaction between variety and crop residues was found to be significant of weed population, dry weight and percent inhibition. The highest weed population (17.33) was found in $V_{3} W_{0}$ (Nizershail $\times$ No residues) followed by $V_{1} W_{0}$ and the lowest was found in $V_{2} W_{2}, V_{2} W_{3}$, and $V_{2} W_{4}$ treatment (Table 2). The highest weed dry weight $\left(9.19 \mathrm{~g}\right.$ ) was found in $\mathrm{V}_{3} \mathrm{~W}_{0}$ (Nizershail $\times$ No residues), and the lowest weed dry weight (1.25) was in $\mathrm{V}_{2} \mathrm{~W}_{2}$ (Binadhan-12 $\times$ Marsh pepper residues at $2.0 \mathrm{t} \mathrm{ha}^{-1}$ ) treatment (Table 2). Percent inhibition of weed was the highest in $V_{2} W_{3}$ (Binadhan-12× Buckwheat residues at $0.5 \mathrm{t} \mathrm{ha}^{-1}$ and marsh pepper residues at $1.0 \mathrm{t} \mathrm{ha}^{-1}$ ) treatment and the lowest one was observed in $\mathrm{V}_{1} \mathrm{~W}_{0}, \mathrm{~V}_{2} \mathrm{~W}_{0}$, and $\mathrm{V}_{3} \mathrm{~W}_{0}$ treatment (Table 2).

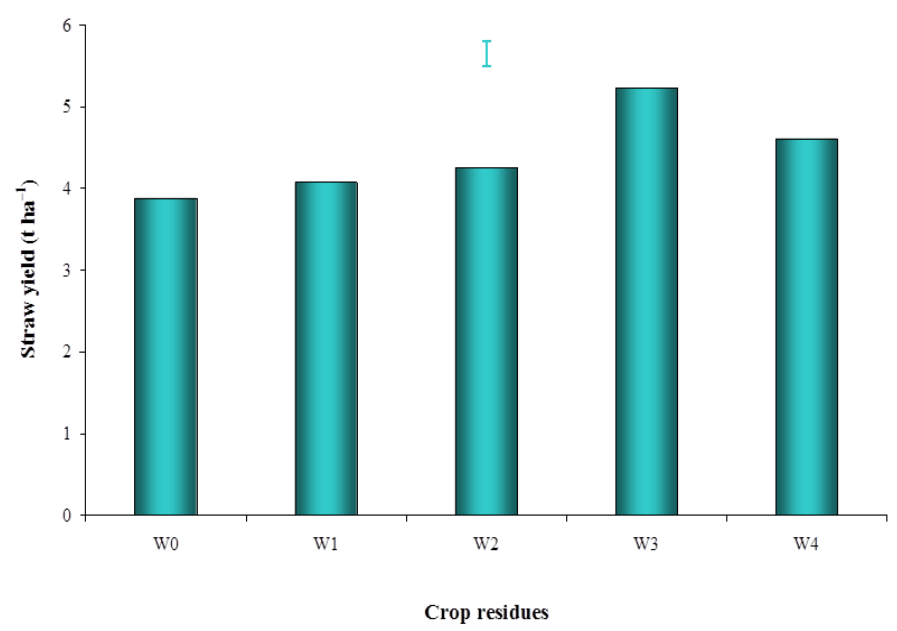

Figure 3. Straw yield as influenced by variety (Bar represents standard error mean).

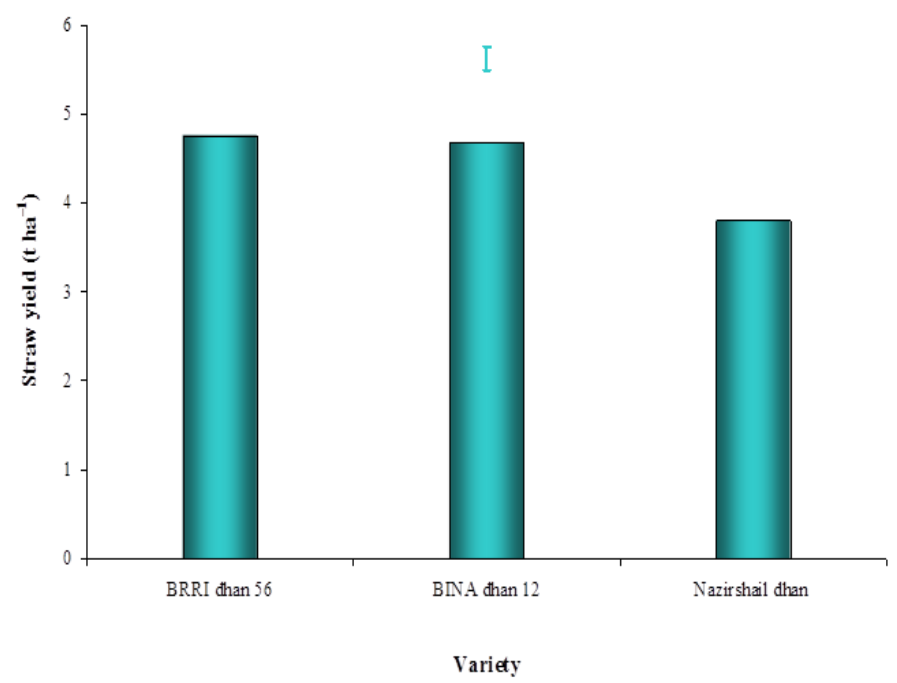

Figure 4. Straw yield as influenced by buckwheat and marsh pepper residues treatment (Bar represents standard error mean). $W_{0}=$ No residues, $W_{1}=$ Buckwheat residues at $2.0 \mathrm{tha}^{-1}, \mathrm{~W}_{2}=$ Marsh pepper residues at $2.0 \mathrm{tha}^{-1}, \mathrm{~W}_{3}=$ Buckwheat residues at $0.5 \mathrm{th} \mathrm{ha}^{-1}$ and marsh pepper residues at $1.0 \mathrm{tha}^{-1}, \mathrm{~W}_{4}=$ Buckwheat residues at $1.0 \mathrm{tha}^{-1}$ and marsh pepper residues at $0.5 \mathrm{tha}^{-1}$. 
Variety and crop residues interaction influence on Pani shapla (Nymphea nouchali)

The interaction between variety and crop residues was found to be significant of weed population, dry weight and percent inhibition (Table 3). The highest weed population (33.33) was found in $\mathrm{V}_{3} \mathrm{~W}_{0}$ (Nizershail $\times$ No residues) followed by $\mathrm{V}_{2} \mathrm{~W}_{0}$ and the lowest (6.67) was found in $\mathrm{V}_{1} \mathrm{~W}_{3}$ (BRRI dhan $56 \times$ Buckwheat residues at $0.5 \mathrm{t} \mathrm{ha}^{-1}$ and marsh pepper residues at $1.0 \mathrm{t} \mathrm{ha}^{-1}$ ) treatment (Table 3). The highest weed dry weight (6.67 g) was found in $\mathrm{V}_{3} \mathrm{~W}_{0}$ (Nizershail $\times$ No residues), and the lowest weed dry weight (0.69) was in $\mathrm{V}_{1} \mathrm{~W}_{3}$ (BRRI dhan56 $\times$ Buckwheat residues at $0.5 \mathrm{t} \mathrm{ha}^{-1}$ and marsh pepper residues at $1.0 \mathrm{t} \mathrm{ha}^{-1}$ ) treatment. Percent inhibition of weed was the highest in $\mathrm{V}_{1} \mathrm{~W}_{3}$ (BRRI dhan $56 \times$ Buckwheat residues at $0.5 \mathrm{t} \mathrm{ha}^{-1}$ and marsh pepper residues at $1.0 \mathrm{t} \mathrm{ha}^{-1}$ ) treatment and the lowest one was observed in $\mathrm{V}_{1} \mathrm{~W}_{0}, \mathrm{~V}_{2} \mathrm{~W}_{0}$, and $\mathrm{V}_{3} \mathrm{~W}_{0}$ treatment (Table 3).

Variety and crop residues interaction influence on sabuj nakphul (Cyperus difformis)

The interaction between variety and crop residues was found to be significant of weed population, dry weight and percent inhibition (Table 4). The highest weed population (22.67) was found in $\mathrm{V}_{3} \mathrm{~W}_{0}$ (Nizershail $\times$ No residues) followed by $\mathrm{V}_{1} \mathrm{~W}_{0}$ and the lowest (1.33) was found in $V_{2} W_{3}$ treatment (Table 4). The highest weed dry weight $\left(9.13 \mathrm{~g}\right.$ ) was found in $\mathrm{V}_{3} \mathrm{~W}_{0}$ (Nizershail $\times$ No residues), and the lowest weed dry weight (1.25) was in $V_{2} W_{2}$ (Binadhan-12 $\times$ Marsh pepper residues at $2.0 \mathrm{t} \mathrm{ha}^{-1}$ ) treatment (Table 4). Percent inhibition of weed was the highest in $\mathrm{V}_{2} \mathrm{~W}_{3}$ (Binadhan-12× Buckwheat residues at $0.5 \mathrm{t} \mathrm{ha}^{-1}$ and marsh pepper residues at $1.0 \mathrm{t} \mathrm{ha}^{-1}$ ) treatment and the lowest was observed in $\mathrm{V}_{1} \mathrm{~W}_{0}, \mathrm{~V}_{2} \mathrm{~W}_{0}$, and $\mathrm{V}_{3} \mathrm{~W}_{0}$ treatment (Table 4).

Variety and crop residues interaction influence on Chechra (Scirpus juncoides)

The interaction between variety and crop residues was found to be significant of weed population, dry weight and percent inhibition (Table 5). The highest weed population (38.67) was found in $\mathrm{V}_{3} \mathrm{~W}_{0}$ (Nizershail $\times$ no residues) followed by $\mathrm{V}_{2} \mathrm{~W}_{0}$ and the lowest (6.67) was found in $\mathrm{V}_{1} \mathrm{~W}_{3}$ (BRRI dhan $56 \times$ Buckwheat residues at $0.5 \mathrm{t} \mathrm{ha}^{-1}$ and marsh pepper residues at $1.0 \mathrm{t} \mathrm{ha}^{-1}$ ) treatment (Table 5). The highest weed dry weight $(6.60 \mathrm{~g})$ was found in $\mathrm{V}_{3} \mathrm{~W}_{0}$ (Nizershail $\times$ No residues), and the lowest weed dry weight (0.57) was in $\mathrm{V}_{1} \mathrm{~W}_{3}$ (BRRI dhan56 $\times$ Buckwheat residues at $0.5 \mathrm{t} \mathrm{ha}^{-1}$ and marsh pepper residues at $1.0 \mathrm{t} \mathrm{ha}^{-1}$ ) treatment (Table 5). Percent inhibition of weed was the highest in $\mathrm{V}_{1} \mathrm{~W}_{3}$ (BRRI dhan56 $\times$ Buckwheat residues at $0.5 \mathrm{t} \mathrm{ha}^{-1}$ and marsh pepper residues at $1.0 \mathrm{t} \mathrm{ha}^{-1}$ ) treatment and the lowest was observed in $\mathrm{V}_{3} \mathrm{~W}_{0}, \mathrm{~V}_{1} \mathrm{~W}_{0}$ and $\mathrm{V}_{2} \mathrm{~W}_{0}$ treatment (Table 5).

Variety and crop residues interaction influence on yield contributing characters and yield

The effect of interaction between variety and crop residues was not significant for plant height (Table 6). Numerically, the tallest plant was obtained from Nizershail in buckwheat residues at 0.5 $\mathrm{t} \mathrm{ha}^{-1}$ and marsh pepper residues at $1.0 \mathrm{t} \mathrm{ha}^{-1}$ and Binadhan-12 produced the shortest plant in no residues treatment. Significant variation was found in number of effective tillers hill ${ }^{-1}$ due to interaction between variety and crop residues (Table 6). The highest number of effective tillers hill $^{-1}$ was produced by BRRI dhan56 in buckwheat residues at $0.5 \mathrm{t} \mathrm{ha}^{-1}$ and marsh pepper residues at $1.0 \mathrm{t} \mathrm{ha}^{-1}$ treatment, while the lowest number of effective tillers hill ${ }^{-1}$ was found from Nizershail in no residues treatment. Panicle length was not significantly influenced by variety and crop residues. However the longest panicle was observed in $\mathrm{V}_{1} \mathrm{~W}_{3}$ (BRRI dhan $56 \times$ Buckwheat residues at $0.5 \mathrm{t}$ $\mathrm{ha}^{-1}$ and marsh pepper residues at $1.0 \mathrm{t} \mathrm{ha}^{-1}$ ) and the shortest one was found in $\mathrm{V}_{3} \mathrm{~W}_{0}$ (Nizershail $\times$ no residues) treatment (Table 6).There was non-significant relationship among interaction of variety and crop residues in case of weight of 1000 grains. But apparently, the highest weight of 1000 grains was recorded in $\mathrm{V}_{1} \mathrm{~W}_{3}$ (BRRI dhan $56 \times$ Buckwheat residues at $0.5 \mathrm{t}$ $\mathrm{ha}^{-1}$ and marsh pepper residues at $1.0 \mathrm{t} \mathrm{ha}^{-1}$ ) treatment.

The studied different varieties significantly affected the grain yield. The highest grain yield $\left(4.19 \mathrm{t} \mathrm{ha}^{-1}\right)$ was obtained in BRRI dhan56 (Figure 1) followed by Binadhan-12 (4.09 $\left.\mathrm{t} \mathrm{ha}^{-1}\right)$. The lowest grain yield $\left(3.31 \mathrm{t} \mathrm{ha}^{-1}\right)$ was obtained in Nizershail (Figure 1). This difference was observed due to different varietal characteristics of rice plant. BRRI (2005) also reported variation in grain yield among the varieties. Grain yield was significantly influenced by buckwheat and marsh pepper residues. The highest grain yield $\left(4.66 \mathrm{t} \mathrm{ha}^{-1}\right)$ was produced by Buckwheat residues at $0.5 \mathrm{t} \mathrm{ha}^{-1}$ and marsh pepper residues at $1.0 \mathrm{t} \mathrm{ha}^{-1}$ treatment, followed by Buckwheat residues at $1.0 \mathrm{t} \mathrm{ha}^{-1}$ and marsh pepper residues at $0.5 \mathrm{t} \mathrm{ha}^{-1}$ treatment $\left(4.08 \mathrm{tha}^{-1}\right)$ and lowest one (3.31 $\mathrm{t} \mathrm{ha}^{-1}$ ) was produced by $\mathrm{W}_{0}$ (no residue) treatment (Figure 2). Uddin and Pyon (2010) also reported the similar results, where crop residues influenced in crop performance.

Straw yield was significantly influenced by three varieties. The highest straw yield $\left(4.75 \mathrm{t} \mathrm{ha}^{-1}\right)$ was found in BRRI dhan56 followed by Binadhan-12 (4.66 tha ${ }^{-1}$ ) and the lowest straw yield (3.80 $\mathrm{t} \mathrm{ha}^{-1}$ ) was found in Nizershail (Figure 3). Straw yield was significantly influenced by buckwheat and marsh pepper residues. The highest straw yield (5.23) was observed in Buckwheat residues at $0.5 \mathrm{t} \mathrm{ha}^{-1}$ and marsh pepper residues at $1.0 \mathrm{t} \mathrm{ha}^{-1}$ treatment and the lowest straw yield (3.88) was observed in $W_{0}$ (no residues) treatment (Figure 4). Biological yield was significantly influenced by the interaction between variety and crop residues. The highest biological yield was produced by $\mathrm{V}_{1} \mathrm{~W}_{3}$ (BRRI dhan $56 \times$ Buckwheat residues at $0.5 \mathrm{t}$ $\mathrm{ha}^{-1}$ and marsh pepper residues at $1.0 \mathrm{t} \mathrm{ha}^{-1}$ ) treatment and the lowest biological yield was produced by $\mathrm{V}_{3} \mathrm{~W}_{0}$ (Nizershail $\times$ no residues) treatment (Table 6 ). Harvest index was significantly influenced by the interaction between variety and crop residues. The highest harvest index was observed in $\mathrm{V}_{1} \mathrm{~W}_{3}$ (BRRI dhan $56 \times$ Buckwheat residues at $0.5 \mathrm{t} \mathrm{ha}^{-1}$ and marsh pepper residues at $1.0 \mathrm{t} \mathrm{ha}^{-1}$ ) treatment and the lowest harvest index was observed in $\mathrm{V}_{3} \mathrm{~W}_{0}$ (Nizershail $\times$ No residues) treatment (Table 6). 
Table 1. Combined effects of variety and buckwheat and marsh pepper residues on number, dry weight and percent inhibition of weed shama in T. aman rice.

\begin{tabular}{|c|c|c|c|}
\hline Variety $\times$ Crop residues & $\begin{array}{l}\text { Number of weed } \\
\text { quadrate }^{-1}(25 \times 25) \mathrm{cm}^{2}\end{array}$ & $\begin{array}{l}\text { Dry weight }(\mathrm{g}) \text { of weed } \\
\text { quadrate }^{-1}(25 \times 25) \mathrm{cm}^{2}\end{array}$ & $\%$ Inhibition of weed \\
\hline $\mathrm{V}_{1} \mathrm{~W}_{0}$ & $4.00 \mathrm{c}$ & $3.33 d$ & $0.00 \mathrm{i}$ \\
\hline $\mathrm{V}_{1} \mathrm{~W}_{1}$ & $1.33 \mathrm{e}$ & $1.98 \mathrm{gh}$ & $40.46 \mathrm{~g}$ \\
\hline $\mathrm{V}_{1} \mathrm{~W}_{2}$ & 1.00 ef & $1.28 \mathrm{j}$ & $60.57 d$ \\
\hline $\mathrm{V}_{1} \mathrm{~W}_{3}$ & $0.47 \mathrm{~g}$ & $0.83 k$ & $74.88 \mathrm{a}$ \\
\hline $\mathrm{V}_{1} \mathrm{~W}_{4}$ & $0.72 \mathrm{fg}$ & $1.06 \mathrm{jk}$ & $67.98 \mathrm{c}$ \\
\hline$V_{2} W_{0}$ & $5.33 b$ & $4.12 c$ & $0.00 \mathrm{i}$ \\
\hline $\mathrm{V}_{2} \mathrm{~W}_{1}$ & $2.67 d$ & 2.53 ef & $38.50 \mathrm{~g}$ \\
\hline $\mathrm{V}_{2} \mathrm{~W}_{2}$ & 1.15 ef & $1.68 \mathrm{hi}$ & $59.14 \mathrm{e}$ \\
\hline $\mathrm{V}_{2} \mathrm{~W}_{3}$ & $0.72 \mathrm{fg}$ & $1.17 \mathrm{jk}$ & 70.52 b \\
\hline $\mathrm{V}_{2} \mathrm{~W}_{4}$ & 0.92 ef & $1.36 \mathrm{ij}$ & $66.83 c$ \\
\hline $\mathrm{V}_{3} \mathrm{~W}_{0}$ & $6.67 a$ & $7.15 a$ & $0.00 \mathrm{i}$ \\
\hline $\mathrm{V}_{3} \mathrm{~W}_{1}$ & $2.67 d$ & $4.66 \mathrm{~b}$ & $34.72 \mathrm{~h}$ \\
\hline $\mathrm{V}_{3} \mathrm{~W}_{2}$ & $1.33 \mathrm{e}$ & $3.16 \mathrm{~d}$ & $55.70 \mathrm{f}$ \\
\hline $\mathrm{V}_{3} \mathrm{~W}_{3}$ & $0.83 \mathrm{fg}$ & $2.28 \mathrm{fg}$ & $68.06 \mathrm{c}$ \\
\hline $\mathrm{V}_{3} \mathrm{~W}_{4}$ & $1.02 \mathrm{ef}$ & $2.63 \mathrm{e}$ & $63.16 \mathrm{~d}$ \\
\hline $\operatorname{LSD}_{0.05}$ & 0.140 & 0.114 & 0.702 \\
\hline Level of sig. & $* *$ & $* *$ & $* *$ \\
\hline
\end{tabular}

In a column, figures with same letter(s) or without letter do not differ significantly whereas figures with dissimilar letter differ significantly as per DMRT ${ }^{* *}=$ Significant at $1 \%$ level of probability. Here, $\mathrm{V}_{1}=\mathrm{BRRI}$ dhan $56, \mathrm{~V}_{2}=$ Binadhan-12, $\mathrm{V}_{3}=$ Nizershail; $\mathrm{W}_{0}=$ No residues, $\mathrm{W}_{1}=$ Buckwheat residues at 2.0 t ha ${ }_{1}^{1}, \mathrm{~W}_{2}=$ Marsh pepper residues at $2.0 \mathrm{tha}^{-1}, \mathrm{~W}_{3}=$ Buckwheat residues at $0.5 \mathrm{t} \mathrm{ha}^{-1}$ and Marsh pepper residues at $1.0 \mathrm{t} \mathrm{ha}^{-1}, \mathrm{~W}_{4}=\mathrm{Buckwheat} \mathrm{residues} \mathrm{at}^{-1}$ $1.0 \mathrm{tha}^{-1}$ and marsh pepper residues at $0.5 \mathrm{tha}^{-1}$.

Table 2. Combined effects of variety and buckwheat and marsh pepper residues on number, dry weight and percent inhibition of weed panikachu in T. aman rice.

\begin{tabular}{|c|c|c|c|}
\hline Variety $\times$ Crop residues & $\begin{array}{c}\text { Number of weed } \\
\text { quadrate }^{-1}(25 \times 25) \mathrm{cm}^{2}\end{array}$ & $\begin{array}{l}\text { Dry weight }(\mathrm{g}) \text { of weed } \\
\text { quadrate }^{-1}(25 \times 25) \mathrm{cm}^{2}\end{array}$ & $\%$ Inhibition of weed \\
\hline $\mathrm{V}_{1} \mathrm{~W}_{0}$ & $14.67 b$ & $4.83 \mathrm{~b}$ & $0.00 \mathrm{~h}$ \\
\hline $\mathrm{V}_{1} \mathrm{~W}_{1}$ & $13.33 c$ & $2.33 f$ & $51.71 f$ \\
\hline $\mathrm{V}_{1} \mathrm{~W}_{2}$ & $12.00 \mathrm{~d}$ & $2.06 \mathrm{f}$ & $57.15 \mathrm{e}$ \\
\hline $\mathrm{V}_{1} \mathrm{~W}_{3}$ & $6.67 \mathrm{~h}$ & $1.28 \mathrm{~g}$ & $73.41 b$ \\
\hline $\mathrm{V}_{1} \mathrm{~W}_{4}$ & $8.00 \mathrm{~g}$ & $0.53 \mathrm{~g}$ & $68.24 c$ \\
\hline $\mathrm{V}_{2} \mathrm{~W}_{0}$ & $12.00 \mathrm{~d}$ & $3.31 \mathrm{~d}$ & $0.00 \mathrm{~h}$ \\
\hline$V_{2} W_{1}$ & $9.33 f$ & $1.46 \mathrm{~g}$ & $55.68 \mathrm{e}$ \\
\hline $\mathrm{V}_{2} \mathrm{~W}_{2}$ & $5.33 \mathrm{i}$ & $1.25 \mathrm{~g}$ & $62.25 \mathrm{~d}$ \\
\hline $\mathrm{V}_{2} \mathrm{~W}_{3}$ & $5.33 \mathrm{i}$ & $0.79 \mathrm{~h}$ & $76.21 \mathrm{a}$ \\
\hline $\mathrm{V}_{2} \mathrm{~W}_{4}$ & $5.33 \mathrm{i}$ & $1.27 \mathrm{~g}$ & $61.69 \mathrm{~d}$ \\
\hline $\mathrm{V}_{3} \mathrm{~W}_{0}$ & $17.33 \mathrm{a}$ & $9.19 a$ & $0.00 \mathrm{~h}$ \\
\hline $\mathrm{V}_{3} \mathrm{~W}_{1}$ & $13.33 c$ & $5.12 b$ & $44.27 \mathrm{~g}$ \\
\hline $\mathrm{V}_{3} \mathrm{~W}_{2}$ & $12.00 \mathrm{~d}$ & $4.13 c$ & $55.03 \mathrm{e}$ \\
\hline $\mathrm{V}_{3} \mathrm{~W}_{3}$ & $8.670 \mathrm{fg}$ & $2.70 \mathrm{e}$ & $70.62 \mathrm{c}$ \\
\hline $\mathrm{V}_{3} \mathrm{~W}_{4}$ & $10.67 \mathrm{e}$ & $3.53 d$ & $60.55 d$ \\
\hline $\mathrm{LSD}_{0.05}$ & 0.325 & 0.117 & 0.953 \\
\hline Level of sig. & $* *$ & $* *$ & $* *$ \\
\hline
\end{tabular}

In a column, figures with same letter(s) or without letter do not differ significantly whereas figures with dissimilar letter differ significantly as per DMRT. ${ }^{* *}=$ Significant at $1 \%$ level of probability. Here, $\mathrm{V}_{1}=\mathrm{BRRI}$ dhan $56, \mathrm{~V}_{2}=$ Binadhan-12, $\mathrm{V}_{3}=$ Nizershail; $\mathrm{W}_{0}=$ No residues, $\mathrm{W}_{1}=\mathrm{Buckwheat}$ residues at $2.0 \mathrm{t}$ ha ${ }_{1}^{1}, \mathrm{~W}_{2}=$ Marsh pepper residues at $2.0 \mathrm{tha}^{-1}, \mathrm{~W}_{3}=$ Buckwheat residues at $0.5 \mathrm{t} \mathrm{ha}^{-1}$ and Marsh pepper residues at $1.0 \mathrm{t} \mathrm{ha}^{-1}, \mathrm{~W}_{4}=\mathrm{Buckwheat} \mathrm{residues} \mathrm{at}^{-1}$ $1.0 \mathrm{tha}^{-1}$ and marsh pepper residues at $0.5 \mathrm{t} \mathrm{ha}^{-1}$. 
Table 3. Combined effects of variety and buckwheat and marsh pepper residues on number, dry weight and percent inhibition of weed pani shapla in T. aman rice.

\begin{tabular}{lccc}
\hline Variety $\times$ Crop residues & $\begin{array}{c}\text { Number of weed } \\
\text { quadrate } \mathrm{e}^{-1}\left(\mathbf{2 5 \times 2 5} \mathbf{c m}^{2}\right.\end{array}$ & $\begin{array}{c}\text { Dry weight }(\mathrm{g}) \text { of weed } \\
\text { quadrate }\end{array}$ & \% Inhibition of weed \\
\hline $\mathrm{V}_{1} \mathrm{~W}_{0}$ & $14.67 \mathrm{~cd} \mathbf{c m}^{2}$ & $3.11 \mathrm{~d}$ & $0.00 \mathrm{j}$ \\
$\mathrm{V}_{1} \mathrm{~W}_{1}$ & $10.67 \mathrm{e}$ & $0.57 \mathrm{hi}$ & $49.35 \mathrm{~h}$ \\
$\mathrm{~V}_{1} \mathrm{~W}_{2}$ & $9.33 \mathrm{ef}$ & $1.20 \mathrm{j}$ & $61.35 \mathrm{e}$ \\
$\mathrm{V}_{1} \mathrm{~W}_{3}$ & $6.67 \mathrm{~g}$ & $0.69 \mathrm{k}$ & $77.68 \mathrm{a}$ \\
$\mathrm{V}_{1} \mathrm{~W}_{4}$ & $9.3 \mathrm{ef}$ & $1.01 \mathrm{jk}$ & $67.29 \mathrm{c}$ \\
$\mathrm{V}_{2} \mathrm{~W}_{0}$ & $18.67 \mathrm{~b}$ & $4.57 \mathrm{~b}$ & $0.00 \mathrm{j}$ \\
$\mathrm{V}_{2} \mathrm{~W}_{1}$ & $14.67 \mathrm{~cd}$ & $2.35 \mathrm{ef}$ & $48.62 \mathrm{~h}$ \\
$\mathrm{~V}_{2} \mathrm{~W}_{2}$ & $10.67 \mathrm{e}$ & $1.91 \mathrm{gh}$ & $58.09 \mathrm{f}$ \\
$\mathrm{V}_{2} \mathrm{~W}_{3}$ & $7.670 \mathrm{fg}$ & $1.24 \mathrm{ij}$ & $72.89 \mathrm{~b}$ \\
$\mathrm{~V}_{2} \mathrm{~W}_{4}$ & $10.67 \mathrm{e}$ & $1.61 \mathrm{~h}$ & $64.65 \mathrm{~d}$ \\
$\mathrm{~V}_{3} \mathrm{~W}_{0}$ & $33.33 \mathrm{a}$ & $6.67 \mathrm{a}$ & $0.00 \mathrm{j}$ \\
$\mathrm{V}_{3} \mathrm{~W}_{1}$ & $16.00 \mathrm{c}$ & $3.61 \mathrm{c}$ & $45.82 \mathrm{i}$ \\
$\mathrm{V}_{3} \mathrm{~W}_{2}$ & $13.33 \mathrm{~d}$ & $2.96 \mathrm{~d}$ & $55.51 \mathrm{~g}$ \\
$\mathrm{~V}_{3} \mathrm{~W}_{3}$ & $9.330 \mathrm{ef}$ & $2.08 \mathrm{fg}$ & $68.76 \mathrm{c}$ \\
$\mathrm{V}_{3} \mathrm{~W}_{4}$ & $10.67 \mathrm{e}$ & $2.55 \mathrm{e}$ & $61.76 \mathrm{e}$ \\
$\mathrm{LSD}_{0.05}$ & 0.645 & 0.118 & 0.844 \\
Level of sig. & $* *$ & $* *$ & $* *$ \\
\hline
\end{tabular}

In a column, figures with same letter(s) or without letter do not differ significantly whereas figures with dissimilar letter differ significantly as per DMRT. ${ }^{* *}=$ Significant at $1 \%$ level of probability. Here, $\mathrm{V}_{1}=\mathrm{BRRI}$ dhan $56, \mathrm{~V}_{2}=$ Binadhan $-12, \mathrm{~V}_{3}=$ Nizershail; $\mathrm{W}_{0}=$ No residues, $\mathrm{W}_{1}=$ Buckwheat residues at $2.0 \mathrm{t}$ ha ${ }^{1}, \mathrm{~W}_{2}=$ Marsh pepper residues at $2.0 \mathrm{t} \mathrm{ha}^{-1}, \mathrm{~W}_{3}=$ Buckwheat residues at $0.5 \mathrm{t} \mathrm{ha}^{-1}$ and marsh pepper residues at $1.0 \mathrm{t} \mathrm{ha}^{-1}, \mathrm{~W}_{4}=\mathrm{Buckwheat} \mathrm{residues} \mathrm{at}^{-1}$ $1.0 \mathrm{tha}^{-1}$ and marsh pepper residues at $0.5 \mathrm{tha}^{-1}$.

Table 4. Combined effects of variety and buckwheat and marshpepper residues on number, dry weight and percent inhibition of weed sabuj nakphul in T. aman rice.

\begin{tabular}{|c|c|c|c|}
\hline Variety $\times$ Crop residues & $\begin{array}{l}\text { Number of weed quadrate }{ }^{-1} \\
\qquad(25 \times 25) \mathrm{cm}^{2}\end{array}$ & $\begin{array}{l}\text { Dry weight }(\mathrm{g}) \text { of weed } \\
\text { quadrate }^{-1}(25 \times 25) \mathrm{cm}^{2}\end{array}$ & $\%$ Inhibition of weed \\
\hline $\mathrm{V}_{1} \mathrm{~W}_{0}$ & $20.00 \mathrm{~b}$ & $9.11 \mathrm{a}$ & $0.00 \mathrm{i}$ \\
\hline $\mathrm{V}_{1} \mathrm{~W}_{1}$ & $8.00 \mathrm{f}$ & $5.73 b$ & $37.08 \mathrm{~h}$ \\
\hline $\mathrm{V}_{1} \mathrm{~W}_{2}$ & $5.33 \mathrm{~g}$ & $3.86 \mathrm{c}$ & $57.55 \mathrm{e}$ \\
\hline $\mathrm{V}_{1} \mathrm{~W}_{3}$ & $2.67 \mathrm{~h}$ & $2.53 \mathrm{e}$ & $72.19 a b$ \\
\hline $\mathrm{V}_{1} \mathrm{~W}_{4}$ & $5.33 \mathrm{~g}$ & $2.83 \mathrm{de}$ & $68.89 \mathrm{~cd}$ \\
\hline $\mathrm{V}_{2} \mathrm{~W}_{0}$ & $10.67 d$ & $3.13 d$ & $0.00 \mathrm{i}$ \\
\hline $\mathrm{V}_{2} \mathrm{~W}_{1}$ & $6.67 \mathrm{fg}$ & $1.75 \mathrm{f}$ & $44.09 \mathrm{~g}$ \\
\hline $\mathrm{V}_{2} \mathrm{~W}_{2}$ & $5.33 \mathrm{~g}$ & $1.25 \mathrm{fg}$ & $60.09 \mathrm{e}$ \\
\hline $\mathrm{V}_{2} \mathrm{~W}_{3}$ & $1.33 \mathrm{~h}$ & $0.80 \mathrm{~g}$ & $74.45 a$ \\
\hline $\mathrm{V}_{2} \mathrm{~W}_{4}$ & $2.67 \mathrm{~h}$ & $0.93 \mathrm{~g}$ & 70.19 bc \\
\hline $\mathrm{V}_{3} \mathrm{~W}_{0}$ & $22.67 a$ & $9.13 \mathrm{a}$ & $0.00 \mathrm{i}$ \\
\hline $\mathrm{V}_{3} \mathrm{~W}_{1}$ & $14.67 \mathrm{c}$ & $5.86 \mathrm{~b}$ & $35.76 \mathrm{~h}$ \\
\hline $\mathrm{V}_{3} \mathrm{~W}_{2}$ & $9.33 \mathrm{e}$ & $4.31 c$ & $52.81 \mathrm{f}$ \\
\hline $\mathrm{V}_{3} \mathrm{~W}_{3}$ & $6.67 \mathrm{fg}$ & $2.75 \mathrm{de}$ & $69.88 \mathrm{bc}$ \\
\hline $\mathrm{V}_{3} \mathrm{~W}_{4}$ & $6.67 \mathrm{~g}$ & $3.06 \mathrm{de}$ & $66.42 d$ \\
\hline $\mathrm{LSD}_{0.05}$ & 0.445 & 0.184 & 1.03 \\
\hline Level of sig. & $* *$ & $* *$ & $* *$ \\
\hline
\end{tabular}

In a column, figures with same letter(s) or without letter do not differ significantly whereas figures with dissimilar letter differ significantly as per DMRT. ${ }^{* *}=$

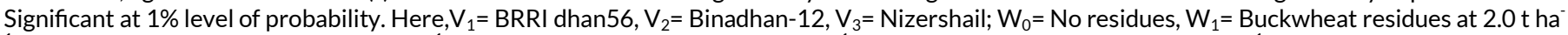
${ }_{1}^{1}, \mathrm{~W}_{2}=$ Marsh pepper residues at $2.0 \mathrm{t} \mathrm{ha}^{-1}, \mathrm{~W}_{3}=$ Buckwheat residues at $0.5 \mathrm{t} \mathrm{ha}^{-1}$ and marsh pepper residues at $1.0 \mathrm{t} \mathrm{ha}^{-1}, \mathrm{~W}_{4}=\mathrm{Buckwheat} \mathrm{residues} \mathrm{at}^{-1}$ $1.0 \mathrm{tha}^{-1}$ and marsh pepper residues at $0.5 \mathrm{tha}^{-1}$. 
Table 5. Combined effects of variety and buckwheat and marsh pepper residues on number, dry weight and percent inhibition of weed chechra in T. aman rice.

\begin{tabular}{|c|c|c|c|}
\hline Variety $\times$ Crop residues & $\begin{array}{l}\text { Number of weed quadrate }{ }^{-1} \\
(25 \times 25) \mathrm{cm}^{2}\end{array}$ & $\begin{array}{l}\text { Dry weight }(\mathrm{g}) \text { of weed } \\
\text { quadrate }^{-1}(25 \times 25) \mathrm{cm}^{2}\end{array}$ & $\begin{array}{c}\% \text { Inhibition of } \\
\text { weed }\end{array}$ \\
\hline $\mathrm{V}_{1} \mathrm{~W}_{0}$ & $21.33 d$ & $6.27 a$ & $0.00 \mathrm{~h}$ \\
\hline $\mathrm{V}_{1} \mathrm{~W}_{1}$ & $20.00 \mathrm{de}$ & $3.23 \mathrm{de}$ & $48.36 \mathrm{de}$ \\
\hline $\mathrm{V}_{1} \mathrm{~W}_{2}$ & $18.67 \mathrm{e}$ & $2.59 \mathrm{~g}$ & $58.56 \mathrm{bc}$ \\
\hline $\mathrm{V}_{1} \mathrm{~W}_{3}$ & $6.67 \mathrm{~h}$ & $0.57 \mathrm{i}$ & $74.79 \mathrm{a}$ \\
\hline $\mathrm{V}_{1} \mathrm{~W}_{4}$ & $8.00 \mathrm{~h}$ & $2.27 \mathrm{~g}$ & $63.62 \mathrm{~b}$ \\
\hline $\mathrm{V}_{2} \mathrm{~W}_{0}$ & $28.00 \mathrm{~b}$ & $6.31 \mathrm{a}$ & $0.00 \mathrm{~h}$ \\
\hline $\mathrm{V}_{2} \mathrm{~W}_{1}$ & $25.33 c$ & $3.50 \mathrm{~d}$ & 44.28 ef \\
\hline $\mathrm{V}_{2} \mathrm{~W}_{2}$ & $24.00 \mathrm{c}$ & $3.27 \mathrm{~d}$ & 48.00 def \\
\hline $\mathrm{V}_{2} \mathrm{~W}_{3}$ & $8.00 \mathrm{~h}$ & $1.93 \mathrm{~h}$ & $69.32 \mathrm{a}$ \\
\hline $\mathrm{V}_{2} \mathrm{~W}_{4}$ & $10.67 \mathrm{~g}$ & 2.91 ef & $53.63 \mathrm{~cd}$ \\
\hline $\mathrm{V}_{3} \mathrm{~W}_{0}$ & $38.67 a$ & $6.60 \mathrm{a}$ & $0.00 \mathrm{~h}$ \\
\hline $\mathrm{V}_{3} \mathrm{~W}_{1}$ & $28.00 \mathrm{~b}$ & $4.16 b$ & $36.87 \mathrm{~g}$ \\
\hline $\mathrm{V}_{3} \mathrm{~W}_{2}$ & $25.33 c$ & $3.83 c$ & $41.92 \mathrm{fg}$ \\
\hline $\mathrm{V}_{3} \mathrm{~W}_{3}$ & $14.67 f$ & $2.59 \mathrm{fg}$ & $60.81 b$ \\
\hline $\mathrm{V}_{3} \mathrm{~W}_{4}$ & $25.33 c$ & $3.45 \mathrm{~d}$ & 47.73 def \\
\hline $\operatorname{LSD}_{0.05}$ & 0.690 & 0.110 & 1.94 \\
\hline Level of sig. & $* *$ & $* *$ & $* *$ \\
\hline
\end{tabular}

In a column, figures with same letter(s) or without letter do not differ significantly whereas figures with dissimilar letter differ significantly as per DMRT. ${ }^{* *}=$ Significant at $1 \%$ level of probability. Here, $\mathrm{V}_{1}=\mathrm{BRRI}$ dhan $56, \mathrm{~V}_{2}=$ Binadhan-12, $\mathrm{V}_{3}=$ Nizershail; $\mathrm{W}_{0}=$ No residues, $\mathrm{W}_{1}=$ Buckwheat residues at $2.0 \mathrm{t}$ ha ${ }_{1}^{1}, \mathrm{~W}_{2}=$ Marsh pepper residues at $2.0 \mathrm{t} \mathrm{ha}^{-1}, \mathrm{~W}_{3}=$ Buckwheat residues at $0.5 \mathrm{t} \mathrm{ha}^{-1}$ and marsh pepper residues at $1.0 \mathrm{t} \mathrm{ha}^{-1}, \mathrm{~W}_{4}=\mathrm{Buckwheat}$ residues at $1.0 \mathrm{t} \mathrm{ha}^{-1}$ and marsh pepper residues at $0.5 \mathrm{tha}^{-1}$.

Table 6. Combined effect of variety and treatment on yield and yield contributing characters of rice.

\begin{tabular}{|c|c|c|c|c|c|c|}
\hline Variety $\times$ Treatment & $\begin{array}{l}\text { Plant height } \\
(\mathrm{cm})\end{array}$ & $\begin{array}{l}\text { No. of effective } \\
\text { tillers hill }\end{array}$ & $\begin{array}{c}\text { Panicle } \\
\text { length }(\mathrm{cm})\end{array}$ & $\begin{array}{l}1000 \text { grain } \\
\text { weight }(\mathrm{g})\end{array}$ & $\begin{array}{l}\text { Biological yield } \\
\left(\mathrm{t} \mathrm{ha}^{-1}\right)\end{array}$ & $\begin{array}{l}\text { Harvest } \\
\text { index (\%) }\end{array}$ \\
\hline $\mathrm{V}_{1} \mathrm{~W}_{0}$ & 117.73 & $6.53 \mathrm{de}$ & 23.32 & 21.83 & 7.87 & 46.18 \\
\hline $\mathrm{V}_{1} \mathrm{~W}_{1}$ & 117.93 & $6.60 \mathrm{de}$ & 24.05 & 23.23 & 8.33 & 46.83 \\
\hline $\mathrm{V}_{1} \mathrm{~W}_{2}$ & 120.67 & $7.87 \mathrm{~b}$ & 24.46 & 24.40 & 8.69 & 46.97 \\
\hline $\mathrm{V}_{1} \mathrm{~W}_{3}$ & 127.33 & $9.13 \mathrm{a}$ & 24.53 & 24.53 & 10.66 & 47.20 \\
\hline $\mathrm{V}_{1} \mathrm{~W}_{4}$ & 123.07 & $8.93 a$ & 24.53 & 24.43 & 9.25 & 47.04 \\
\hline $\mathrm{V}_{2} \mathrm{~W}_{0}$ & 95.27 & $5.97 \mathrm{fg}$ & 23.16 & 21.60 & 7.63 & 46.07 \\
\hline $\mathrm{V}_{2} \mathrm{~W}_{1}$ & 97.80 & 6.33 ef & 23.91 & 22.30 & 8.10 & 46.49 \\
\hline $\mathrm{V}_{2} \mathrm{~W}_{2}$ & 97.87 & 6.73 cde & 23.91 & 23.30 & 8.40 & 46.84 \\
\hline $\mathrm{V}_{2} \mathrm{~W}_{3}$ & 109.40 & $9.07 \mathrm{a}$ & 24.46 & 23.43 & 10.51 & 47.10 \\
\hline $\mathrm{V}_{2} \mathrm{~W}_{4}$ & 98.60 & $7.20 \mathrm{c}$ & 24.40 & 23.37 & 9.19 & 46.97 \\
\hline $\mathrm{V}_{3} \mathrm{~W}_{0}$ & 143.67 & $5.67 \mathrm{~g}$ & 21.68 & 20.77 & 6.12 & 45.78 \\
\hline $\mathrm{V}_{3} \mathrm{~W}_{1}$ & 148.07 & $6.23 \mathrm{ef}$ & 22.06 & 21.40 & 6.47 & 46.39 \\
\hline $\mathrm{V}_{3} \mathrm{~W}_{2}$ & 149.00 & $6.53 \mathrm{de}$ & 22.14 & 22.17 & 6.86 & 46.32 \\
\hline $\mathrm{V}_{3} \mathrm{~W}_{3}$ & 151.40 & $8.33 b$ & 23.14 & 22.37 & 8.50 & 47.04 \\
\hline $\mathrm{V}_{3} \mathrm{~W}_{4}$ & 149.60 & $6.87 \mathrm{~cd}$ & 22.92 & 22.23 & 7.63 & 46.82 \\
\hline $\mathrm{LSD}_{0.05}$ & 3.05 & 0.164 & 0.499 & 0.603 & 0.171 & 0.413 \\
\hline Level of sig. & NS & $* *$ & NS & NS & NS & NS \\
\hline CV (\%) & 4.29 & 3.95 & 3.67 & 4.59 & 3.58 & 0.53 \\
\hline
\end{tabular}

In a column, figures with same letter(s) or without letter do not differ significantly whereas figures with dissimilar letter differ significantly as per DMRT. ${ }^{* *}=$ Significant at $1 \%$ level of probability. ${ }^{*}=$ Significant at $5 \%$ level of probability; NS $=$ Not significant; Here, $V_{1}=B R R I$ dhan $56, V_{2}=B i n a d h a n-12, V_{3}=$ Nizershail; $\mathrm{W}_{0}=$ No residues, $\mathrm{W}_{1}=$ Buckwheat residues at $2.0 \mathrm{t} \mathrm{ha}^{-1}, \mathrm{~W}_{2}=$ Marsh pepper residues at $2.0 \mathrm{t} \mathrm{ha}^{-1}, \mathrm{~W}_{3}=$ Buckwheat residues at $0.5 \mathrm{t}$ ha ${ }^{-1}$ and marsh pepper residues at $1.0 \mathrm{t} \mathrm{ha}^{-1}, \mathrm{~W}_{4}=$ Buckwheat residues at $1.0 \mathrm{t} \mathrm{ha}^{-1}$ and marsh pepper residues at $0.5 \mathrm{t} \mathrm{ha}^{-1}$. 


\section{Conclusion}

From the above results and discussion it was found that the variety $B R R I$ dhan 56 and $W_{3}$ (Buckwheat residues at $0.5 \mathrm{t} \mathrm{ha}^{-1}$ and marsh pepper residues at $1.0 \mathrm{t} \mathrm{ha}^{-1}$ ) treatment exhibited the superior effect followed by Binadhan-12 and $W_{4}$ (Buckwheat residues at $1.0 \mathrm{t} \mathrm{ha}^{-1}$ and marsh pepper residues at $0.5 \mathrm{t} \mathrm{ha}^{-1}$ ) treatment for most of the studied traits. Results of present study reveal that combined effect of buckwheat and marsh pepper residues showed herbicidal activity for suppressing weed growth. Therefore, buckwheat and marsh pepper residues could be a potential source of weed management tool for sustainable crop production.

Open Access: This is open access article distributed under the terms of the Creative Commons Attribution License, which permits unrestricted use, distribution, and reproduction in any medium, provided the original author(s) and the source are credited.

\section{REFERENCES}

Bari, M.N., Mamun, A.A. and Anwar S.M.S. (1995). Weed infestation in transplant aman rice as affected by land topography and time of transplanting. Bangladesh Journal of Agricultural Science, 22(2): 227-235.

BBS (2011). Statistical Year Book of Bangladesh, Bureau of Statistics, Statistics Division, Ministry of planning, Government of the People's Republic of Bangladesh, Dhaka. pp. 32-50.

BBS (2013). Monthly Statistical Bulletin of Bangladesh, Bureau of Statistics, Statistics Division, Ministry of planning, Government of the People's Republic of Bangladesh, Dhaka. pp. 71.

BRRI (2008). Annual Report for 2007. Bangladesh Rice Research Institute, Joydevpur, Bangladesh. pp. 28-35.
BRRI (2005). Adhunik Dhaner Chash. Bangladesh Rice Research Institute, Joydevpur, Gazipur, Bangladesh. pp. 12, 20-21, 23.

FAO (2009). Production Year Book. Food and Agric. Organ. Of the United Nations, Rome. 45: 72-73.

Gomez, M.A. and Gomez, A.A. (1984). Statistical Procedures for Agricultural Research. John Willey and Sons. New York, Chichester, Brisbane, Toronto. pp. 207-215.

Inderjit, Dakshini, K.M., and Foy C.L. (1999). Principles and practices in plant ecology: allelochemical interaction. CRC Press LLC, USA, 589s.

Keely, P.E. (1987). Interference and interaction of purple and yellow nutsedge (C. rotundus and C. esculentus) with crops. Weed Technology, 1(1): 74-81, https://www.jstor.org/ stable/3986987

Mamun, A.A. (1990). Weeds and their control: A review of weed research in Bangladesh. Agricultural and Rural Development in Bangladesh. Japan International Co-operation Agency, Dhaka, Bangladesh. JSARD. 19, 45-72.

Mukhopadhyay, S.K. and Ghose, D.C. (1981). Weed problems in oil seed and its control. Pesticide Information, 7(4): 44.

Nandal, D.P. and Singh, C.M. (1994). Effect of weed control on direct seeded puddle rice. Haryana Agricultural University Journal of Research, 24(4): 154-157.

Uddin, M.R. and Pyon, J.Y. (2010). Herbicidal Activity of Rotation Crop Residues on Weeds and Selectivity to Crops. Journal of Agricultural Science, 37(1): 1-6.

UNDP and FAO (1988). Land Resources Appraisal of Bangladesh for Agricultural Development Report No. 2. Agro-ecological Regions of Bangladesh. United Nations Development Programme and Food and Agricultural Organization, Rome., Italy. pp. 212-221.

Walia, U.S., Singh, D. and Brar, L.S. (2006). Weed management in rice raised with different sowing techniques. Journal of Research of Punjab Agricultural University, 43: 94-97. 